\title{
Music in Early Childhood Education: Its Importance in Selected Child Development
}

\author{
Esimone, Chinyere Celestina (Ph.D.) \\ Ojukwu, Ebele Veronica \\ Department of Music. Nnamdi Azikiwe University, \\ Awka, Anambra State, Nigeria \\ admireesomchi@yahoo.com,drebeleojukwu@yahoo.com
}

\section{Doi:10.5901/jesr.2014.v4n1p39}

\begin{abstract}
Music is one excellent subject whose importance transcends what men generally sees it to be. Hence they see it as solely for entertainment. Obviously the importance and benefits of music transcend its entertainment objective. Music is said to be a universal language of the soul, and as such can achieve more vital issues than ordinary words or other subjects can ever achieve. Its role in early childhood education in the social, psychological and spiritual development of the children surpasses what mere words can explain. Unfortunately many parents and childhood educators are quite ignorant of this and as such struggles in these areas. It is this unfortunate situation that this paper is out to address; hence it $x$-rays the role of music in the social, moral and spiritual life of the children in early childhood.
\end{abstract}

\section{Introduction}

Music is a natural and important part of young children's growth and development. Anyone who has worked with young children knows that children love music and can engage in musical activities on many levels. In fact, early interaction with music positively affects the quality of all areas of children's lives (Esimone, 2012:1).

Music obviously plays much role in the life of the children which later defines their outlook in life; and much more in their social, psychological and spiritual lives. But the perception of most people, if not all the persons; such as parents, childhood educators, general public and so on, on music as solely for entertainment had brought about the non harnessing of music to help the children develop in the areas mentioned above. It is the hope of this researcher that this paper will be an eye opener to the role that music can actually play in the development of the aspects of lives of children mentioned above.

\section{Music}

One will want to ask, what is music? Music has many definitions. Blacking (1973) defined it as "an organised sound that pleases the ear" (p. 57). Agu (2006) described it to be "an aesthetic art of combining or putting together sounds that are pleasant to the ear" (p. 1). Hence music is in everywhere and form that it exist, according to the people's culture, whether that culture is Western or African. Ekong (2008) says it is a universal language of expression hence it is humanly conceived and practiced and used to express human emotions, culture, feelings, ideas and events (p. 17). Ekong (2008:17) further asserts:

Music is what gives a society life and cultural identity. People the world over value music as part of their culture. Its transmission starts from the home and its continuity is propagated by the larger society. Traditionally, this process has been done orally, with the indigenes imbibing the musical culture through observing, imitating and participating in musical events. In contemporary times, technological development has brought music to every door step (p. 17).

It is this above statement that provoked Ekpo (2008) to succinctly say:

The child's heritage in music comes first from his parents, relatives and other members of his immediate environment. Many children develop interest in music before they enter elementary schools. Their parents introduced them into cradle songs, moonlight songs, game songs, basic dance movements, marches and instrument playing. Most of these 
pre-elementary school activities have greatly helped in developing the children's feeling for pulse, phrase and pitch (p. 30).

Ekpo (2008) further said:

The child's first lessons in music are given by his mother. Immediately after birth, the child is placed on the mother's back while she goes about her daily tasks. Accompanied by the child, she washes clothes in the river, pounds cassava to rhythm, dances and sings. He learns what the music requires in terms of both bodily movement and vocal effort ( $p$. 30).

The above statement obviously shows music is cultural and universal. It is a phenomenon that appeals to all human, and very applicable to all situations of life, hence its importance in the development of the child can never be overemphasised.

Of all the beautiful things in this world, few surpass the images of music in childhood. Our own earliest memories are rich with music: soft lullabies on a parent's lap; patty-cake rhymes in the nursery; parade music played by brass bands that marched in time; seasonal songs at the dinner table, at the piano, or around the campfire; chants for jumping rope and clapping hands; and the music played with friends on homemade instruments. Music played a prominent role in our childhood then, as it still does for children today (Campbell \& Kassner 2010)

Music obviously occupies a central place in the life of every human and in all works of life, and therefore works as incentives in almost all things.

\section{Education}

Education is one important factor that can not be done away with because it takes place every now and then, consciously and unconsciously. For the child, every thing is about learning, hence they learn by observation, imitation and practice. In the musical learning of a child, education is the foundation and the bedrock, whether on the parents' lap, sibling or nurse; or even within the four walls of an established institution of learning, education is the pillar. It is very obvious and clear that learning can not be said to have taken place in the absence of education. Hence, education has enjoyed a wide range of definitions. Brembeck (1971) believes that "education is a device by which men and women take what others before them have learnt to the next generation" (p.287). Akande (2002) says "it is the cornerstone of any nation that contributes to its development" (p. 26). Akinbote (2008) asserts "it is a process by which the community seeks to open its life to all the individuals within it to enable them take their part in it" (p. 8).

Education is a process of acculturation through which the individual is helped to attain the development of his potentialities, and the maximum activation when necessary, according to right reason and to achieve thereby his perfect self-fulfillment (Okafor 1992). And Onuora-oguno (2009), in agreeing with Okafor (1992) says: "education has been portrayed by many sociologist and educationists to be an experience which bothers on the people's culture, and which through learning prepares an individual for adult life in his particular society" (p. 73)

All the definitions above point to one fact, acquisition of skills, whatever it is meant for, must come through learning which education is the source; and music education in early childhood education is the foundation through which the knowledge and benefits of music especially, in the general development of the child in early childhood could easily be achieved. Hence Nketia in Ajewole (2010) concluded when he asserts:

People were not educated merely for music; rather music was a basis for educating the members of the community and music serves as a means of teaching the norms and values of the society by which individuals are accepted as good members of the society (p. 17).

\section{The Role of Music in Early Childhood Education}

Music emerges magically from children, as they search for and find ways to represent their world. Intuitively and naturally, young children respond to music as they communicate through it. Music is part of their process of enculturation. They develop as members of their family, their neighbourhood community, and their religious and ethnic groups through music. Children learn a musical system-its tuning, timbres, predominant pitch and rhythmic patterns, textures and formal structures-as surely as they learn other aspects of their family and then their community cultures. They are socialised into these groups through music and are deeply rooted in this first musical system early in childhood (Campbell \& Kassner 2010). 
Music is as important as life hence it empowers and instills all the necessary qualities an individual needs, to explore the world around him. Music making is a basic skill in life and as a result has so much to do with man's emotions, moods, feelings, attitudes and opinions. It is desirable therefore for children to experience its full benefit especially in their social, psychological and spiritual lives. This section will explain these aspects in details.

\title{
5. Social Development
}

Social life is seen as an aspect of life that deals with interaction with people from different works of life. It is the ability of an individual to freely relate and interact in a more comfortable way with an individual different from an original background. Social life is about self esteem and self-expression. Children naturally are known to have attachment with members of their families, and most times finds it very difficult to relate with others (fellow children inclusive) of whom they have not seen before. And naturally, many of them are shy.

This situation most times brings about difficulties of getting a child into a kindergarten or pre-primary school and play grounds where other children are found. At least it is a natural occurrence for two to three times before that child could adjust and relax with other children. Most times parents or guardians have to stay and then disappear when the child is distracted by watching either the teacher or other children in their activities, and will start crying on realisation that the companion has disappeared. This indeed is a problem. And it is as a result of the ignorance of the incentive that music brings about in the social life of the children. But watch a child's reaction in a musical environment, especially the school environment, the first few minutes will have the child watching the environment and other children's participation; the next reaction of the child will be to join the group and participate on what is going on.

The child does not only join and participate, the child will at the same time make friends with other children right there. It is so if the activity last for an hour or more. Friendships that most times are inseparable takes place immediately, because music is involved. Such occasions takes place not only in schools or play ground, but in birthday parities and other child oriented activities. Several times, they will want their parents or guardians to leave them behind and go, simply because music is involved. This incident has been observed by the researcher several times and has made her conclude that, indeed inherent in music does not only lie in its entertainment ability, but also in enhancing the social life of the children in early childhood.

To this Onyiuke (2006) expressed:

Music has the potential for being one of the most valuable subjects for enhancing the human personality, through complete involvement in inquiry techniques and creative approaches to learners (p. 57).

Music obviously strengthens children's ability to form attachments to other people than their parents. As Esimone (2012) observed:

\begin{abstract}
Children learn to share and cooperate with those around them, play well with others and show more self-control hence singing and playing together gets rid of selfishness in them. And as part of their social interaction, playing and singing together as children, helps them deal with ups and downs that are faced with playing and interacting with fellow children. Some times, they are so excited and happy; at other times, they misunderstand themselves and fall out in their interactions, such as the way they feel when it happens, and the way in which they deal with their emotion are all vital part of their growing up and developing socially; music obviously helps them achieve this (p. 57).
\end{abstract}

When children play and sing together, they seem to relate well with themselves. This obviously leads to their having a sense of belonging and that within the group of their play. This togetherness in their play reaps them off the negative attitudes they seem to have such as discrimination, disrespect and taking one another for granted; and rather have the opposite attitudes of love, tolerance and respect for one another. This is one of the most important attitude one needs in life to fit in properly in the society, in order to respect the dignity of fellow human being irrespective of colour, race or tribe. And this they are able to acquire quite early in life through music.

Caregivers or teachers and parents are helpers in bringing about this social relationship. As Esimone (2012) noted:

It is obvious that caregivers or the teachers and parents are helpers in causing this social relationship become part of their lives. They encourage their playing and singing together with other children, irrespective of their background or short comings both at home, parks and school environment where they find themselves. Some children are introverts while others are extroverts. It is as they relate and play with other children that they understand themselves; their 
temperaments develop and grow in a better way as they rob off on themselves. With the presence of the caregivers or teachers and parents, they are able to be paired to blend very well. And little by little, the introverts who will in the process discover their extrovert's peers and make friends with them will be seen becoming calm and relaxed, and of course form good and real relationships (p. 57).

All the above stated facts are possible because children generally love music as do the adults, but tend to appreciate it more than the adults. One wonders at the miracle that singing does to a hungry, crying and unhappy child. Mere singing for the child brings such emotional traits to a halt, and resumes when the music stops. That's the power of music in early childhood education.

\section{Psychological Development}

The importance of music in the psychology of children is one important aspect of their development that is being neglected by both parents and teachers in the early childhood, specifically because of ignorance.

Psychology according to the Oxford Advance Learner's Dictionary (2006) is defined as "the scientific study of the mind and how it affects behaviour" (p. 941). This definition implies that the state of the mind can actually affect the outcome of behaviour. A child with a mental dullness obviously is not expected to be happy, or even think his life is worth living, because he is different from others especially in the school.

Besides most children seem unintelligent compare to their siblings and friends, and have most times been called names such as block-heads, never-do-wells and looked down upon. Such situation to mention but few, obviously gives children impression they are not loved, unimportant and useless. Some children with certain illnesses that make them look unacceptable to fellow children for no fault of theirs have problems adjusting psychologically. This state of mind not only affects the psychological life of the child but the general development. These situations and circumstances should not have occurred if people (parents, caregivers and the general public) were aware of the power of music. As Parlakian \& Lerner (2010), rightly said:

Music has power and meaning that go beyond words. First and most important, sharing music with young children is simply one more way to give love and receive love. Like all the best learning experiences in early childhood, music activities simultaneously promote development in multiple domains. Singing a lullaby while rocking a baby stimulates early language development, promotes attachment, and supports an infant's growing spatial awareness as the child experiences her body moving in space" (p. 1).

Music is sincerely highly motivational and it can have a calm and relaxing effect on the listener and participant. Enjoying music activities that are success oriented makes children feel better about themselves; it also help stimulate all their sensory organs. Singing lullabies for children all the time the opportunity arises as parents at home; and giving children opportunities to participate in making music either in singing, dancing and playing together with fellow children as caregivers and teachers in school go a long way to help children feel good about themselves; and have their problems improved tremendously.

Hence, every child should be given the opportunity of listening to, and participating in music making, as well as playing any musical instrument of their choice is an antidote to psychological imbalance.

\section{Spiritual Development}

Spirituality is one aspect of life that is very important in every individual's life. This life is all about God and man hence the importance of being conscious and connected to God in life can never be overemphasised. Every soul needs God, and the knowledge of God should start very early in life. The Holy Bible made it clear when it says: "the fear of God is the beginning of wisdom, through it, men depart from evil" (Prov. 9:10). The same Holy Book declared: "Remember now thy Creator when the evil days have not come, nor the years gone far, when thou shall say, I have no pleasure in them" (Ecclesiastes 12:1).

Introduction to God and His knowledge should start quite early in life. Most families abhor this and forbid its teaching in schools, but none is against it when songs are involved. Leader \& Hynie (1958) observed that "the teaching of religion in the schools possess controversy and sectarianism, but music transcends these barriers, and goes to their very heart" (p. 26). This made Plato to declare "Great music is that which penetrates the ear with facility and leaves the memory with difficulty. Magical music never leaves the memory. A song will outlive all sermon in the memory".

Music gets children in tuned with God early in their life; it introduces them to their maker and makes them have the 
consciousness of God in their hearts as they grow up. This helps to keep them safe and guided in their choices of either good or evil, and in dedication in their choices of carrier and vocation in the future. Coles (1990), in his thirty (30) years dedication in researching on children's spirituality across the United States and the world; met with hundreds of children whose spirituality were developed at home, churches, synagogues and mosques. He discovered that children are drawn to soul searching through songs, even though religion is not part of their lives. He interacted with students and engaged them in meaningful discussions and emotional debates about spirituality from which he quoted what one inner city child said about his connection to God through singing in church.

... I was singing in church last Sunday and I taught that God must be enjoying us, because we were hitting all the notes right! Then when we were through, and were just sitting there ... I was thinking that God put me here so I could sing like I just did... I'll wait to see what He thinks I should do when I'm older (p. 136).

In supporting the above statement, Elliot, (1995) observed that:

Music education improves one's health, mind and soul and twentieth century educators are becoming increasingly aware of, and responsive to, children's spirituality need. The art, particularly music, possesses creative and critical thinking elements to nurture the spiritual needs of children. A spiritual musical environment is both a reflection of, and an inspiration to the entire school community (p. 16).

Music no doubt provides children with a means of self-expression. Now that there is relative security in the basics of existence, the challenge is to make life meaningful and to reach for a higher stage of development. Every one needs to be in touch at some time in his life, with what he feels and who he is. Self-esteem is a by-product of this self-expression which often comes when children participate in singing. Music performance and participation teaches children to conquer fear and to take risks. A little anxiety is a good thing and something that will occur often in life. Dealing with it early and often makes it less of a problem later. Risk-taking is essential if a child is to fully develop his potential. No doubt, music education exposes children to the incomparable (Esimone, 2007).

\section{References}

Ajewole, J. O. (2010). The role of music teacher education in the achievement of universal basic education (UBE). Awka Journal of Research in Music and The Arts. ARRMA. 7: 14 - 21

Akande, F. F. (2002). Teacher education and national development in the $21^{\text {st }}$ century: Challenges and strategies for improvement. Ilorin Journal of Teacher Education. 1: 2-35

Akinbote, O. (2008). Universal basic education in Nigeria: prospects and problem. A Lead paper presented at the $3^{\text {rd }}$ National Conference, School of Education, Federal College of Education, Osiele, Abeokuta [15th August 2000]

Agu, D. C. C. (2006). The Nigerian Policy on Education: Its impact on music education programme and delivery in Nigeria. Awka Journal of research in music and the arts (AJRMA). 3: 1-8.

Blacking, J. (1973). How Musical is Man? London: Faber \& Faber.

Brembeck, C. (1971). Social Foundations of Education. New York: John Woly \& Sons.

Campbell, P. S. \& Kassner, C. S. (2010). Music in childhood: from preschool through the Elementary grades. Boston: Schimer;

Coles, R. (1990). The Spiritual Life of Children. Boston: Houghton Mifflin.

Ekong, G. E. (2008). Recreating music for self-reliance and patriotism. Awka Journal of Research in Music and the Arts. 5, 16-25

Ekpo, I. S. (2008). Parental factor in early musical exposure as a prerequisite for Ideal musical development of the child: Nigeria's experience. Awka Journal of Research in Music and the Arts (AJRMA), 5, 26-34

Elliot, D. J. (1995). Music matters: a new philosophy of music education. New York: Oxford Uninversity Press.

Esimone, C. C. (2007). Music education and social identity: A study of selected Secondary schools in Enugu State. A Master's desertation presented at the University of Nigeria, Nsukka.

Esimone, C. C. (2012) Music in early childhood education: a study of selected pre-primary schools in Anambra State, Nigeria. A Ph.D. thesis presented at the Nnamdi Azikiwe University, Awka.

Leader, J. A. \& Haynie, W. S. (1958). Music Education in the High School. Englewood, NJ: Pretence Hall.

Okafor, R.C. (1992). Concepts of functional education. Owerri: Totan Publishers Ltd.

Okafor, R. C. (2005). Music in Nigerian society. Enugu: New Generation.

Onuora-Oguno, N. C. (2009). Expanding the frontiers of music education in Igbo-land in the $21^{\text {st }}$ century using minstrelsy as a tool. Awka Journal of Research in Music and the Arts (AJRMA), 6, 70 - 75

Onyiuke, Y. S. (2006). Music pedagogy as implement for all round development of primary school children in Nigeria. INTERLINK: $A$ Journal of Research in Music. 3,56-63.

Parlakian, R. \& Lerner, C. (2010). Beyond Twinkle, Twinkle: Using music with infants and toddlers. http:/l:www.naeyc.org/yc/permissions 
